\title{
Birdlime in Western Myanmar: Preparation, Use, and Conservation Implications for an Endemic Bird
}

\author{
Steven G. Platt ${ }^{1}$, Kalyar Platt ${ }^{2}$, Thet Zaw Naing ${ }^{1}$, Hong Meng ${ }^{3}$, Win Ko Ko ${ }^{1}$, Naing Lin ${ }^{1}$, Robert J. Tizzard ${ }^{1}$,
} Khin Myo Myo ${ }^{1}$, Me Me Soe ${ }^{2}$, Thomas R. Rainwater ${ }^{4}$

Author address: ${ }^{1}$ Wildlife Conservation Society, Myanmar Program, Hlaing Township, Yangon, Myanmar, ${ }^{2}$ Turtle Survival Alliance, Hlaing Township, Yangon, Myanmar, ${ }^{3}$ Natma Taung National Park, Kampetlet, Myanmar, ${ }^{4}$ U.S. Fish and Wildlife Service, Charleston Field Office, Charleston, South Carolina, USA.

trrainwater@gmail.com

Received: September 24, 2012

Volume: 3:68-75

Published: December 17, 2012

(C) 2012 Society of Ethnobiology

\begin{abstract}
Birdlimes are adhesive entangling compounds that passively capture birds by binding them to a substrate and rendering flight feathers useless. We investigated birdlime use among indigenous Chin hunters during a wildlife survey of Natma Taung National Park (NTNP) in western Myanmar (May-June 2011). We found that birdlime is prepared from the sap of various banyan trees (Ficus spp.) collected during the annual dry season (December-May). Birdlime is prepared by boiling sap to remove water, and the finished product is a readily malleable and extremely adhesive compound known locally as nghet phan te kaw ("bird glue"). Hunters employ four principal strategies when using birdlime: 1) limed sticks are placed at waterholes and springs; 2) limed sticks are placed in fruiting trees or nocturnal roost sites; 3) limed sticks are positioned at prominent vantage points and hunters mimic vocalizations to attract birds; 4) small insects (possibly termites) are affixed to a limed pole and serve as bait to attract birds. Large numbers (>200) of birds can reportedly be captured during a single day by hunters using birdlime. At least 186 (63.9\%) of 291 species of birds occurring in Natma Taung National Park are thought to be vulnerable to this non-selective hunting strategy. The endangered white-browed nuthatch (Sitta victoriae Rippon Sittidae), a poorly-studied endemic species restricted to high elevation Oak-Rhododendron forest in NTNP, is vulnerable to birdliming, although the impact of hunting on populations remains unclear. We recommend that future investigations determine the sustainability of the Chin bird harvest by relating hunter off-take to recruitment and survivorship of nuthatches. If conservation action is deemed prudent, management plans should be developed in close collaboration with local Chin communities.
\end{abstract}

Key Words: Birdlime, Ficus, Natma Taung National Park, traditional hunting, white-browed nuthatch

\section{Introduction}

Hunting is a behavior of primary importance in the physical and social evolution of humans (Cartmill 1993) and information on traditional hunting and trapping methodologies is of interest to anthropologists, archaeologists, biologists, conservationists, and wildlife managers (Gilchrist et al. 2005; Shaffer 1996). Such information not only enhances our understanding of indigenous folkways and patterns of resource exploitation among traditional societies (Shaffer 1996), but on occasion can be adapted by professional biologists to meet research objectives (McClure 1956; van Vliet et al. 2009).

Birdlimes are a class of adhesive entangling compounds used to capture birds (MacPherson 1897) by binding them to a substrate and rendering their flight feathers useless (Alves et al. 2010; Fitzwater 1982). Birdlime has a long history of use in many parts of the world with the earliest written records in the West dating to ancient Greece (MacPherson 1897). Birdlime was a particularly important hunting strategy before modern firearms became widely available (MacPherson 1897). Although most effective against smaller avifauna, birdlime has also been employed to capture large birds such as waterfowl, cranes, raptors, and pheasants (MacPherson 1897). Insects (MacPherson 1897) and small mammals (Fitzwater 1982) can also be taken by "liming", and Burton (1918) even reported observing indigenous hunters capturing tigers (Panthera tigris L. Felidae) with birdlime in India.

Birdlime is traditionally prepared from adhesive 
resins and gums obtained from a wide variety of plants, often mixed with vegetable oils or turpentine to improve malleability (Fernandes-Ferreira et al. 2012; Fitzwater 1982; MacPherson 1897). Occasionally plant-based dyes are included to camouflage the mixture (Alves et al. 2010). Although numerous plant sources of birdlime have been documented (MacPherson 1897), reports describing the preparation of these compounds are notably absent from the literature (Fitzwater 1982). In this article, we describe various aspects of birdlime use among Chin hunters of western Myanmar. We identify the plants used to manufacture birdlime, outline the preparation process, describe how hunters deploy birdlime to capture birds, and discuss the conservation implications of these practices.

\section{Study Area and Methods}

The use of birdlime by indigenous hunters was investigated as part of a wildlife survey of Natma Taung National Park (NTNP) in the southern Chin Hills of western Myanmar (Platt et al. 2012). NTNP encompasses $722 \mathrm{~km}^{2}$ of mountainous terrain that includes Mount Victoria (elevation 3,095 m), the highest mountain in central Myanmar. The Chin Hills are inhabited by Chin, a Tibeto-Burman people comprising one of the largest ethnic groups in Myanmar (Diran 2001). The Chin are swidden agriculturalists who derive much of their protein from hunting, fishing, and free-range livestock (Carey and Tuck 1896; Diran 2001). At least 78 villages, containing 12,000 total inhabitants, are located within the boundaries of NTNP, and shifting cultivation, hunting, and other forms of resource extraction are widespread despite the protected status of the area (Platt et al. 2012; Thet Zaw Naing 2003). The topography, vegetation, and wildlife of the Chin Hills are described in greater detail elsewhere (Carey and Tuck 1896; Sayer 1983; Thet Zaw Naing 2003).

We conducted fieldwork in NTNP from 24 May to 14 June 2011. During this period we visited Chin villages in the park where we conducted open-ended interviews (Martin 1995) of individual hunters. Because most Chin are proficient in a variety of hunting methodologies (e.g., flintlock muskets, crossbows, traps, snares, nets, and birdlime) that are variously used depending on the species sought, we followed McCulloch et al. (1992) and defined "hunter" as any person who harvests wildlife irrespective of the method employed (i.e., projectile weapons or passive techniques such as traps, snares, nets, and birdlime). In accordance with the format of openended interviews, we asked each individual a series of questions that included standard questions prepared in advance and others that arose during the course of conversation (Martin 1995). On several occasions, where it was not possible to interview single individuals, we met with groups of hunters simultaneously. In such cases we used a semi-directive approach (Gilchrist et al. 2005), in which information was recorded as questions were asked and discussed more informally.

Interviewees were selected with the assistance of village leaders, and interviews were conducted in Burmese by native Burmese speakers. Interviewees who spoke only Chin were interviewed by one of us (HM) who is fluent in both Chin and Burmese. We began each interview by explaining the objectives of the wildlife survey and the role of the interviewee(s) in our research. Questions about birdlime were embedded in a larger set of questions regarding the local occurrence and population status of wildlife (with an emphasis on large mammals, primates, and turtles), hunting and collecting methods, and levels of harvest. Concerning birdlime we specifically asked: 1) do you use birdlime to capture birds?; 2) what plants are used to make birdlime?; 3) what parts of these plants are used to produce birdlime?; 4) what time of year do you harvest these plant materials?; 5) could you describe the collection process?; 6) could you describe the preparation process?; 7) how is birdlime stored?; 8) how is birdlime used to capture birds?; and 9) how many birds can you catch in a single day using birdlime? Initially we queried interviewees about the species of birds captured with birdlime, but this question was discontinued due to confusion surrounding the local avian folk taxonomy. Transcripts and summaries of interviews are contained in the field notes of Steven G. Platt archived in the Campbell Museum, Clemson University, Clemson, South Carolina, USA.

\section{Results}

We interviewed 47 Chin hunters, all of whom claimed familiarity with birdlime suggesting this hunting strategy is widespread in the region. Birdlime is known locally as nghet phan te kaw, which translates literally as "bird glue". Interviewees stated that wild birds are considered a delicacy among the Chin, and described a complex hierarchal system of reciprocal food offerings, in which a person who is offered one food (e.g., domestic chicken) reciprocates with the offer of a 
higher ranking food (e.g., wild birds). Birds are also sold in the local bushmeat trade and harvested for their plumage, which bedecks traditional headgear. Birdlime is just one strategy among many used to harvest wild birds. Hunters also described taking birds with muzzle-loading flintlock muskets charged with locally manufactured gunpowder, slingshots, nets, snares, and bamboo traps.

According to interviewees, birdlime is prepared from the viscous sap of banyan trees (Ficus L. Moraceae; Figure 1). Ficus benghalensis L. and F. infectoria Willd. are the preferred sources, although other Ficus (F. religiosa L., F. nervosa B. Hayne ex Roth, and F. citrifolia Mill.) are tapped if the preferred species are unavailable. Sap collection is a seasonal activity and while March-April is regarded as the optimal harvest period, trees can be tapped at any time during the dry season (December-May). Banyan trees are tapped in much the same manner as rubber (Hevea brasiliensis Mull. Arg. Euphorbiaceae); shallow diagonal grooves are cut into the cambium, which channel the sap downward into a collection receptacle. Truncated cuts $(7-10 \mathrm{~cm})$ are made in the cambium because banyan sap is extremely viscous and unlike rubber, will flow only a short distance before coagulating. A bamboo culm (ca. $30-40 \mathrm{~cm}$ long) is attached vertically to the bole to collect flowing sap. Once the bamboo culm becomes filled, the sap rapidly hardens into a solid mass. The culm is later split lengthwise, and the congealed mass scraped out and boiled slowly for several hours depending on the amount of sap collected. Boiling serves to remove water from the sap and increase the adhesiveness of the final product. The resulting birdlime is a black, strong-smelling, extremely adhesive, readily malleable compound.

Hunters handle birdlime without it adhering to the skin by first wetting their fingers with water or saliva. Birdlime is stored in a variety of non-edible gourd, reportedly for periods of up to 10 years. According to interviewees, birdlime maintains its adhesive properties even when stored in unsealed containers for long periods. Birdlime can also be reused multiple times, after being cleaned of dirt, leaves, and other debris. Cleaning is accomplished by boiling birdlime and skimming debris from the surface before allowing it to cool. Some hunters now substitute traditionally prepared birdlime with commercially available entangling compounds designed to catch rodents. Commercial rat glue is widely available, relatively inexpensive, easy to use, and requires no time-consuming preparation as does birdlime.

Birdlime is smeared on sticks or other surfaces where birds are likely to alight and become entrapped. Lengths of bamboo are often used as a liming substrate owing in part to its widespread availability. Bamboo is also relatively light in comparison to wood, making it easy to transport and place high in the canopy. Four principal strategies for deploying birdlime emerged from our interviews. The most common seems to be the placement of limed sticks at waterholes and springs where flocks congregate. This strategy is generally employed during the hottest months of the dry season (February-April) and, according to Sayer (1983), is particularly effective at higher elevations where water sources are limited. Hunters described occluding parts of a waterhole with large leaves to funnel birds into a restricted area where limed sticks offer conveniently located perches. A second widely used strategy is to place limed sticks in fruiting trees where birds congregate to feed, or in thickets where large numbers gather to roost every night. A third method described by hunters is to place limed sticks at prominent vantage points (e.g., above the canopy), and after concealing themselves, attract birds by imitating vocalizations. Birds arriving to investigate the vocalizations alight on the perches and become entrapped. Finally, hunters described a method in which small winged insects that emerge en masse at certain times of the year (possibly termites), are captured and impaled on sharpened slivers of wood, which in turn are affixed to a limed pole. Birds attracted by the insects alight on the limed pole.

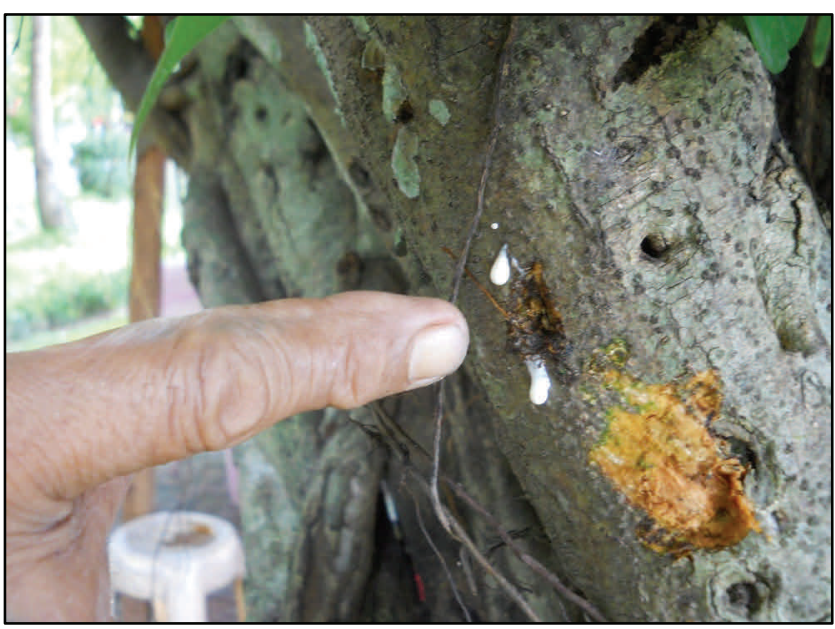

Figure 1. Indigenous hunters in the Chin Hills of western Myanmar prepare birdlime from the viscous sap of banyan trees (Ficus spp.). Photograph by Win Ko Ko. 
Despite being impaled, it is important that the insects remain alive, as their wing movements are said to attract birds.

Large numbers $(>200)$ of birds can reportedly be captured during a single day by an individual hunter using birdlime. Often so many birds are captured that hunters tally their harvest according to the number of baskets required to transport the catch, rather than count the individual birds. Based on our interviews, birdlime appears to be a relatively non-selective hunting strategy, whereby any small to medium-sized bird coming into contact with a limed surface is likely to be trapped. Although we were unable to determine which species are taken by liming, descriptions provided by hunters suggest that smaller birds (e.g., babblers, bulbuls, flycatchers, barbets, warblers, and finches) comprise the bulk of the catch. Larger birds such as hornbills and pheasants are generally taken by shooting or snaring, respectively.

\section{Discussion}

The use of birdlime by indigenous hunters in Chin State and adjacent Nagaland has been noted elsewhere (Carey and Tuck 1896; Saul 2005; Sayer 1983; Thet Zaw Naing 2003), although in contrast to our report, sparse detail is provided in these earlier accounts. According to Carey and Tuck (1896:217), "pigeons and doves are caught with bird-lime, which is nothing more than the gum of a tree and which is smeared on the boughs of the trees which birds frequent". Saul (2005:65) stated the Naga use "...sticky secretions from trees or seeds to trap small birds". Sayer (1983) observed small birds being trapped for food using birdlime smeared on sticks placed at mountain springs. Thet Zaw Naing (2003) listed "gum traps" among the methods employed by hunters in Natma Taung National Park to harvest small birds for domestic consumption and sale in local bushmeat markets.

Literature sources list a number of plants used to prepare birdlime elsewhere in South and Southeast Asia. Banyan sap is widely used throughout Asia, parts of Africa, and the Mediterranean to manufacture birdlime (MacPherson 1897). Similar to our findings, Burton (1918) identified F. religiosa as a source of birdlime in India. Other important plant sources in the region include Cordia myxa L. Boraginaceae (Hutchinson 1918), Lorantbus odoratus Wall. Loranthaceae (Kunwar et al. 2005), Viscum album L. Viscaceae (Kunwar et al. 2005), various unspecified Dipterocarpaceae (Bourke 1925), and Artocarpus beterophyllus Lam. Moraceae (Reidinger and Libay 1979); the latter of which is reportedly capable of restraining birds as large as hornbills (Maynahan 2009). Birdlime is derived from various parts of these plants, including mucilaginous fruits (Kunwar et al. 2005), crushed cambium (MacPherson 1897), fresh sap (MacPherson 1897; Reidinger and Libay 1979), and resins (Bourke 1925). While ethnobotanists have identified numerous plants used to make birdlime (Fitzwater 1982), our report appears to be among the few that describe the preparation process (see also Hiscox 1914; Kunwar et al. 2005; MacPherson 1897). Similar to our findings, MacPherson (1897: xxxii) stated that birdlime can be preserved for an "indefinite period" when properly prepared and stored in "reed vessels".

Our study and others (Sayer 1983; Thet Zaw Naing 2003) found that Chin hunters use birdlime exclusively to harvest birds for food and feathers. However, liming is a versatile technique that has been employed worldwide for a variety of reasons, including recreation and sport, agricultural crop protection, destruction of urban pest species, capturing birds for culinary reasons and to obtain feathers for the millenary trade, and capturing living birds for falconry, pets, and zoological specimens (Alves et al. 2010; Fernandes-Ferreira et al. 2012; Fitzwater 1982; Gibson 1881; MacPherson 1897; Reidinger and Libay 1979). When birdlime is employed for the latter purpose, birds must be rapidly released or will otherwise quickly succumb to exhaustion (Alves et al. 2010). Unfortunately, there is no evidence in the literature to indicate how birds are extracted from birdlime without injury and what techniques are used to clean this adhesive compound from feet and feathers when living birds are desired. This question warrants future investigation, as birdlime, like some other indigenous hunting techniques (e.g., McClure 1956), could prove an effective tool for research and conservation.

The strategies used by Chin hunters to deploy birdlime are similar to those reported wherever this methodology is employed to capture birds (Fernandes -Ferreira et al. 2012; Fitzwater 1982; MacPherson 1897). The over-riding concern is to place birdlime in a manner that ensures physical contact with some part of the bird. Limed perches seem be the most common method of deploying birdlime (FernandesFerreira et al. 2012; MacPherson 1897; Reidinger and Libay 1979). Birds are often attracted to limed perches 
by bait in the form of food or water, vocalizations made by hunters, or decoy birds, which are usually conspecifics, but sometimes predatory species such as owls or hawks (Fernandes-Ferreira et al. 2012; MacPherson 1897). In the latter case, hunters take advantage of mobbing behavior that passerines often exhibit towards predatory birds. Limed perches can also be placed at locations where flocks regularly congregate (e.g., nocturnal roosts and fruiting trees). Birdlime smeared on hanging strings has been used to ensnare flying birds (MacPherson 1897). Waterfowl and cranes have been captured by liming the inside of a baited paper cone, which becomes stuck as it covers the head when birds attempt to reach the bait, thereby compromising their vision. Disoriented and unable to fly properly, birds are quickly seized by concealed hunters waiting nearby (MacPherson 1897). Nectivorous birds have been captured by smearing birdlime on the inside of flowers (Gibson 1881). Indeed, effective strategies for deploying birdlime seem limited only by the ingenuity of hunters and their knowledge of bird habits and behavior.

Consistent with our results, there is general agreement in the literature that birdliming is a highly effective non-selective hunting strategy that results in the harvest of large numbers of birds. According to MacPherson (1897) thousands of passerines were harvested every day with birdlime during the passage

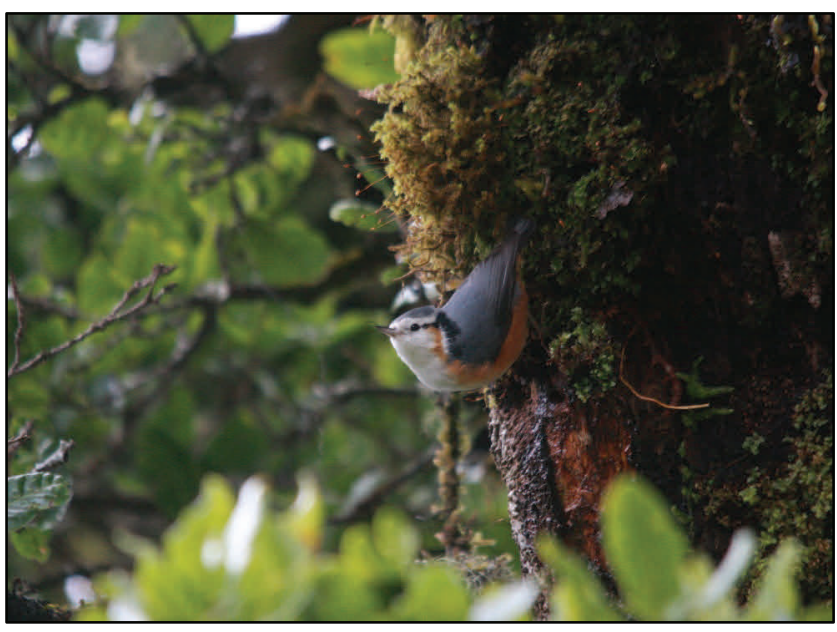

Figure 2. The white-browed nuthatch is endemic to high elevation Oak-Rhododendron forests on Mount Victoria where populations are likely to be at risk from continuing habitat loss and climate change. Hunting with birdlime, acting in concert with habitat loss could potentially exacerbate population declines of this endangered species. Photograph by Thet Zaw Naing. of migratory flocks through southern Europe. More recently, McCulloch et al. (1992) estimated that 2 million birds were harvested annually in Cyprus with a combination of birdliming and mist netting. However, aside from general qualifiers such as "thousands", "whole flocks", or "great numbers", studies which more specifically quantified the harvest of birds taken with birdlime or compared this method with other hunting strategies seem not to have been undertaken. Such data are a necessary prerequisite for assessing the potential impact of this hunting strategy on bird populations.

\section{Conservation Implications}

Concern regarding the population-level impacts of birdlime use in NTNP appear warranted given the ubiquity of this hunting strategy among hunters, the large number of birds evidently harvested with birdlime, and the elevated levels of hunting activity within the park despite its protected status (Platt et al. 2012; Thet Zaw Naing 2003). Based on body size, behavior, and ecology, we conservatively estimate that $186(64.2 \%)$ of 291 species of birds known to occur in NTNP (Thet Zaw Naing 2003 and unpubl. data) are potentially vulnerable to entrapment with birdlime.

Of particular concern is the white-browed nuthatch (Sitta victoriae Rippon Sittidae), a poorlystudied endemic species restricted to OakRhododendron forests above 2,400 $\mathrm{m}$ on Mount Victoria and adjacent peaks (Figure 2; Thet Zaw Naing 2003). The white-browed nuthatch is classified as Endangered by the International Union for Conservation of Nature (IUCN), and populations are thought to be declining for reasons not fully understood, but probably at least partly due to habitat loss (IUCN 2012). Nuthatch populations may also be at risk from climate change, as elevational habitat zones undergo an upwards shift in response to warming temperatures, greatly reducing or perhaps potentially even eliminating existing Oak-Rhododendron forest (Peh 2007).

We regard nuthatches as especially vulnerable to birdliming owing to their small body size and habitat requirements; these birds occur at elevations where springs are the only dry season water source, and such sites are favored locations for setting out limed sticks (Sayer 1983; this study). Although hunter accounts describing the taxonomic composition of harvests proved difficult to interpret, that nuthatches are taken by birdlime is unequivocal. While conducting fieldwork in the park during 1997-2001, one of us (TZN) 
encountered numerous birds entangled in birdlime, including five white-browed nuthatches. Additionally, Forest Department rangers reportedly found whitebrowed nuthatches entangled in birdlime near popular bird watching sites in the park as recently 2011-12 (Naing Lin, unpubl. data).

Given its restricted natural distribution, coupled with predicted reductions in habitat, hunting with birdlime could potentially exacerbate current population declines of the white-browed nuthatch. However, it remains unclear what, if any role hunting plays in the dynamics of nuthatch populations, and without rigorous quantitative data on densities, recruitment, annual survivorship, and rates of hunter off-take (Milner-Gulland et al. 2003), any conclusion regarding the sustainability of the Chin bird harvest would be premature and at best, speculative. Although intensive hunting of rare species can result in extinction (Fernandes-Ferreira et al. 2012), many populations of small birds appear resilient in the face of moderate hunting pressure; hunting mortality is often not additive to natural mortality, and density-dependent processes seem to compensate for hunting losses such that breeding populations are ultimately unaffected (McCulloch et al. 1992). We therefore recommend that future investigators address the sustainability of Chin bird hunting by first quantifying the harvest and then relating hunter off-take to annual recruitment and survivorship among nuthatch populations.

If conservation action is deemed prudent to insure the long-term viability of nuthatch populations, any forthcoming management plan should be developed in close collaboration with local Chin communities, taking into account the social, cultural, and economic factors that drive the harvest of small birds (Alves et al. 2012; Fernandes-Ferreira et al. 2012). Without the active participation of indigenous hunters in the planning and implementation of conservation initiatives, such efforts are unlikely to prove effective (Alves et al. 2012; Rao et al. 2011). This is especially true in Myanmar where resources for enforcement are extremely limited, and implementing effective conservation measures depends on enlisting the cooperation of local communities (Rao et al. 2011).

\section{Acknowledgements}

This project was made possible through the generous support of Andy Sabin, the Sabin Family Foundation, and the Turtle Conservation Fund. U Than Myint and the Wildlife Conservation Society-Myanmar Program are thanked for organizing the expedition and providing logistic support. We are especially grateful for the assistance of U Tin Myat Soe (Park Warden of Natma Taung National Park) for facilitating our fieldwork and sharing his extensive knowledge of the area. Further gratitude is due the Myanmar Forest Department staff and others who accompanied us into the field. Additional support was provided by Colin Poole, Joe Walston, Lisa Yook, and the WCS Asia Program. Madeline Thompson is thanked for locating numerous obscure references. Additional references were provided by Lewis Medlock, Elizabeth Bennett, Rômulo Alves, and Madhu Rao. We are grateful to Thom Hiers for translating a Brazilian source into English. Comments by Lewis Medlock and two anonymous reviewers on an early draft of this manuscript were most appreciated. The findings and conclusions in this article are those of the authors and do not necessarily represent the views of the U.S. Fish and Wildlife Service.

\section{Declarations}

Permissions: Permission to conduct research in western Myanmar and among indigenous communities in the region was granted by the Nature and Wildlife Conservation Division of the Myanmar Forest Department. Our research is also in compliance with institutional guidelines of the Wildlife Conservation Society and Turtle Survival Alliance.

Sources of funding: This research was funded by a grant from the Andy Sabin Family Foundation and Turtle Conservation Fund. Salary support for most participants was provided by the Wildlife Conservation Society's Myanmar Program.

Conflicts of interest: None.

\section{References Cited}

Alves, R. R. N., E. E. G. Nogueira, H. F. P. Araujo, and A. E. Brooks. 2010. Bird-keeping in the Caatinga, NE Brazil. Human Ecology 38:147-156. Doi:10.1007/s10745-009-9295-5

Alves, R. R. N., M. B. R. Gonçalves, and W. L. S. Vieira. 2012. Caça use e Conservação de Vertebrados no Semiárido Brasileiro. Tropical Conservation Science 5:394-416.

Bourke, D. 1925. Monkey Trainers and Bird Catchers in Pattani, South Siam. Indian Forester 51:1-4.

Burton, R. W. 1918. Notes from the Oriental Sporting Magazine. New Series 1869-1879. Journal of the 
Bombay Natural History Society 25:491-493.

Carey, B. S. and H. N. Tuck. 1896. The Chin Hills: A History of Their People, Our Dealings with Them, Their Customs and Manners, and a Gazetteer of Their Country. Vol. 1. Government Printing Office, Rangoon, Burma.

Cartmill, A. 1993. A View to a Death in the Morning. Harvard University Press, Cambridge.

Diran, R. K. 2001. The Vanishing Tribes of Burma. Sterling Publishing, New York.

Fernandes-Ferreira, H., S. V. Medonça, C. Albano, F.S. Ferreira, and R. R. N. Alves. 2012. Hunting, use and conservation of birds in Northeast Brazil. Biodiversity and Conservation 21:221-244.

Doi:10.1007/s10531-011-0179-9

Fitzwater, W. D. 1982. Bird Limes and Rat Glues Sticky Situations. Proceedings $10^{\text {th }}$ Vertebrate Pest Conference 10:17-20.

Gibson, W. H. 1881. Camp Life in the Woods and the Tricks of Trapping and Trap Making. Harper and Brothers, Publishing, New York.

Gilchrist, G., M. Mallory, and F. Merkel. 2005. Can Local Ecological Knowledge Contribute to Wildlife Management? Case Studies of Migratory Birds. Ecology and Society 10:20-31.

Hiscox, G. D. 1914. Henley's Twentieth Century Formulas, Recipes, and Processes. Norma W. Henley Publishing Company, New York.

Hutchinson, J. 1918. Cordia myxa and Allied Species. Bulletin of Miscellaneous Information (Royal Botanic Gardens, Kew) 7:217-222.

IUCN. 2012. IUCN Red List of Threatened Species. Version 2012.1. Available at: http:// www.iucnredlist.org Accessed on June 29, 2012.

Kunwar, R. M., N. Adhikari, and M. P. Devkota. 2005. Indigenous Use of Mistletoes in Tropical and Temperate Regions of Nepal. Banko Janakari $15: 38-42$.

MacPherson, H. A. 1897. A History of Fowling. David Douglas, Edinburgh, Scotland.

Martin, G. J. 1995. Ethnobotany: A Methods Manual. Chapmen Hall, London.

Maynahan, B. 2009. Jungle Soldier: the True Story of Freddy Spencer Chapman. Quercus Press, London.
McCulloch, M. N., G. M. Tucker, and S. R. Ballie. 1992. The Hunting of Migratory Birds in Europe: A Ringing Recovery Analysis. Ibis 134(supplement):5565.

McClure, H. E. 1956. Methods of Bird Netting in Japan Applicable to Wildlife Management Problems. Bird-banding 27:67-73.

Milner-Gulland, E. J., E. L. Bennett, and SCB 2002 Annual Meeting Wild Meat Group. 2003. Wild Meat: The Bigger Picture. Trends in Ecology and Evolution 18:351-357. Doi:10.1016/S0169-5347(03) 00123-X

Peh, K. S. H. 2007. Potential Effects of Climate Change on Elevational Distribution of Tropical Birds in Southeast Asia. Condor 109:437-441.

Platt, S. G., Win Ko Ko, Kalyar Platt, Khin Myo Myo, Me Me Soe and T. R. Rainwater. 2012. Species Inventory and Conservation Status of Chelonians in Natma Taung, National Park, Myanmar. Hamadryad (In press).

Rao, M., Than Zaw, Saw Htun, and Than Myint. 2011. Hunting for a Living: Wildlife Trade, Rural Livelihoods, and Declining Wildlife in Hkakaborazi National Park, North Myanmar. Environmental Management 48:158:167. Doi:10-1007/s00267-0119662-z.

Reidinger, R. F., Jr., and J. L. Libay. 1979. Perches Coated with Glue Reduce Bird Damage in Rice Field Plots. Proceedings $8^{\text {th }}$ Bird Control Seminar, Bowling Green State University 8:201-204.

Saul, J. D. 2005. The Naga of Burma: Their Festivals, Customs and Way of Life. Orchid Press, Bangkok, Thailand.

Sayer, J. A. 1983. A Survey of Natma Taung (Mount Victoria), Southern Chin Hills. Field Report 20, FO: BUR/80/006. Report to Food and Agriculture Organization of the United Nations, Rangoon.

Shaffer, B. S. 1996. Prehistoric Small Game Snare Trap Technology, Deployment Strategy, and Trapper Gender Depicted in Mimbres Pottery. Journal of Ethnobiology 16:145-155.

Thet Zaw Naing. 2003. Ecology of the White-browed Nuthatch Sitta victoriae in Natmataung National Park, Myanmar, With Notes on Other Significant Species. Forktail 19:57-62. 
(f) ETHNOBIOLOGY LeTters $\quad$ Research Communication

van Vliet, N., E. Kaniowska, M. Bourgarel, C.

Fargeot, and R. Nasi. 2009. Answering the Call!

Adapting a Traditional Hunting Practice to Monitor

Duiker Populations. African Journal of Ecology 47:393-

399.

\section{Biosketch}

Steven G. Platt is the Regional Herpetologist for Wildlife Conservation Society in Southeast Asia. He received his B.Sc. in Forestry and Wildlife Management from Louisiana State University (1985), M.Sc. in Biology from Southeastern Louisiana University (1990), and Ph.D. in Zoology from Clemson University (1996). His current focus is the study and conservation of turtles and crocodilians in Southeast Asia, with an emphasis on Myanmar, Thailand, Laos, and China. 